\title{
A IMPORTÂNCIA DO CONHECIMENTO DO PARENTESCO NA EDUCAÇÃO ESCOLAR INDÍGENA INTERCULTURAL DO POVO JAVAÉ
}

\section{Ricardo Tewaxi Javaé \\ Orientador de estudo}

Introdução: Para trabalhar na sala de aula com os alunos da escola o conhecimento dos parentescos, o qual tem o seu significado os cumprimentos na nossa Cultura, muito importante para os mais jovens da nossa comunidade saber valorizar nos nossos dias de hoje devido a globalização que está entrando nas comunidades indígenas.

Justificativa: A valorização dos cumprimentos para o povo Javaé, contribuir o saber dos parentescos e respeito na comunidade, praticar mais na nossa cultura.

A importância das minhas pesquisas para que o povo Javaé retorne o uso dos cumprimentos na comunidade, porque faz parte da nossa cultura o conhecimento dos nossos ancestrais, hoje em dia ocorre perigo de perder pelo mais novo para não se deixar de usar os cumprimentos na comunidade.

Objetivo: Estudar os parentescos e a importância dos cumprimentos e fortalecer a valorização do conhecimento do nosso povo Javaé.

Metodologia: Através da pesquisa com o mais velho da aldeia que sabe todo tipo de cumprimento e também qual e como a fala masculina e a feminina, então assim mais velho contribui muito com o seu conhecimento porque hoje em dia os mais jovens não praticam mais nossa cultura.

Desenvolvimento: Foi uma aula explicativa como eram praticados os cumprimentos e respeito na cultura antigamente, era seu significado e a sua importância e quem fazia o cumprimento, que está dentro de casa ou quem fazia o cumprimento e quem ensina as crianças aprender e conhecer o seu parentesco e como deve cumprimentar.

Conclusão: Meus alunos gostaram da aula porque essas aulas foram elaboradas através da minha pesquisa com o mais 
velho da aldeia, porque os alunos não tiveram esse conhecimento de cumprimentação na cultura, alguns alunos falaram que tiveram vergonha de fazer o cumprimento com seus parentes, primos, tios maternos, tios paternos. Então assim foram as aulas, por isso que os meus alunos gostaram. 